Article

\title{
Highly Red Light-Emitting Erbium- and Lutetium-Doped Core-Shell Upconverting Nanoparticles Surface-Modified with PEG-Folic Acid/TCPP for Suppressing Cervical Cancer HeLa Cells
}

\author{
Kyungseop Lim ${ }^{1}$, Hwang Kyung Kim ${ }^{1} \mathbb{1}$, Xuan Thien Le ${ }^{1}$, Nguyen Thi Nguyen ${ }^{1}$, \\ Eun Seong Lee ${ }^{2} \mathbb{D}$, Kyung Taek $\mathrm{Oh}^{3}{ }^{3}$, Han-Gon Choi ${ }^{4}\left(\mathbb{D}\right.$ and Yu Seok Youn ${ }^{1, *}$ \\ 1 School of Pharmacy, Sungkyunkwan University, 2066 Seobu-ro, Jangan-gu, Suwon, \\ Gyeonggi-do 16419, Korea; imkyung424@naver.com (K.L.); hkkim0319@naver.com (H.K.K.); \\ lexuanthien.dkh@gmail.com (X.T.L.); ngtnguyen1710@gmail.com (N.T.N.) \\ 2 Division of Biotechnology, The Catholic University of Korea, 43 Jibong-ro, Bucheon, \\ Gyeonggi-do 14662, Korea; eslee@catholic.ac.kr \\ 3 College of Pharmacy, Chung-Ang University, 84 Heukseok-ro, Dongjak-gu, Seoul 06974, Korea; \\ kyungoh@cau.ac.kr \\ 4 College of Pharmacy, Hanyang University, 55 Hanyangdaehak-ro, Sangnok-gu, Ansan 15588, Korea; \\ hangon@hanyang.ac.kr \\ * Correspondence: ysyoun@skku.edu; Tel.: +82-31-290-7785
}

Received: 20 October 2020; Accepted: 13 November 2020; Published: 17 November 2020

\begin{abstract}
Photodynamic therapy (PDT) combined with upconverting nanoparticles (UCNPs) are viewed together as an effective method of ablating tumors. After absorbing highly tissue-penetrating near-infrared (NIR) light, UCNPs emit a shorter wavelength light $(\sim 660 \mathrm{~nm})$ suitable for PDT. In this study, we designed and prepared highly red fluorescence-emitting silica-coated core-shell upconverting nanoparticles modified with polyethylene glycol ( $\mathrm{PEG}_{5 \mathrm{k}}$ )-folic acid and tetrakis(4-carboxyphenyl)porphyrin (TCPP) (UCNPs@SiO $\left.2-\mathrm{NH}_{2} @ \mathrm{FA} / \mathrm{PEG} / \mathrm{TCPP}\right)$ as an efficient photodynamic agent for killing tumor cells. The UCNPs consisted of two simple lanthanides, erbium and lutetium, as the core and shell, respectively. The unique core-shell combination enabled the UCNPs to emit red light without green light. TCPP, folic acid, and PEG were conjugated to the outer silica layer of UCNPs as a photosensitizing agent, a ligand for tumor attachment, and a dispersing stabilizer, respectively. The prepared UCNPs of $\sim 50 \mathrm{~nm}$ diameter and $-34.5 \mathrm{mV}$ surface potential absorbed $808 \mathrm{~nm}$ light and emitted $\sim 660 \mathrm{~nm}$ red light. Most notably, these UCNPs were physically well dispersed and stable in the aqueous phase due to PEG attachment and were able to generate singlet oxygen $\left({ }^{1} \mathrm{O}_{2}\right)$ with a high efficacy. The HeLa cells were treated with each UCNP sample $(0,1,5,10,20,30 \mu \mathrm{g} / \mathrm{mL}$ as a free TCPP). The results showed that the combination of UCNPs@SiO $-\mathrm{NH}_{2} @ \mathrm{FA} / \mathrm{PEG} / \mathrm{TCPP}$ and the $808 \mathrm{~nm}$ laser was significantly cytotoxic to HeLa cells, almost to the same degree as naïve TCPP plus the $660 \mathrm{~nm}$ laser based on MTT and Live/Dead assays. Furthermore, the UCNPs@SiO $-\mathrm{NH}_{2} @ \mathrm{FA} / \mathrm{PEG} / \mathrm{TCPP}$ was well internalized into HeLa cells and three-dimensional HeLa spheroids, presumably due to the surface folic acid and small size in conjunction with endocytosis and the nonspecific uptake. We believe that our UCNPs@SiO${ }_{2}-\mathrm{NH}_{2} @ \mathrm{FA} / \mathrm{PEG} / \mathrm{TCPP}$ will serve as a new platform for highly efficient and deep-penetrating photodynamic agents suitable for various tumor treatments.
\end{abstract}

Keywords: upconverting nanoparticles; photodynamic therapy; tetrakis(4-carboxy-phenyl)porphyrin; near infrared; cancer; hypoxia 


\section{Introduction}

Photodynamic therapy (PDT) has attracted great interest as an effective means of treating cancers [1-3]. PDT utilizes photosensitizers (PS) that absorb visible light and convert molecular oxygen to reactive oxygen species (ROS) such as singlet oxygen $\left({ }^{1} \mathrm{O}_{2}\right)$ or other free radicals $[2,4]$. The generated ROS oxidizes cellular proteins, leading to tumor ablation via such mechanisms as direct tumor cell killing, damage to tumor vasculature, and tumor suppression [5,6]. Cancer cells can be killed by the photodynamic process through several mechanisms of apoptosis, necrosis, or autophagy [5]. Necrosis is triggered by a high dose of PS/light and involves cytoplasm swelling, organelle devastation, or membrane disruption, whereas apoptosis is characterized by cell shrinkage, chromosomal DNA fragmentation, or chromatin condensation [5,7].

In the context of an intratumoral injection or tumor targeting approach, PDT has the clear advantage of localizing tumor therapy by irradiating light selectively on the tumor location, with less invasiveness and fewer side effects [5]. In addition, the treatment is of short duration, is inexpensive, and induces an immune response that can produce synergistic effects on anticancer activity $[8,9]$. However, the clinical use of PDT is often restricted because most photosensitizers are activated around a wavelength of $\sim 660 \mathrm{~nm}$, which cannot penetrate the skin deeply when compared to near-infrared (NIR) light ( 780-940 nm) [1,10-12].

Upconverting nanoparticles (UCNPs) have unique optical properties that convert NIR light to UV or visible light [13], which enables many biomedical applications, such as bioimaging, photodynamic therapy, and combined cancer therapy [14-17]. The concept of UCNPs is based on the anti-Stokes phenomenon, in which two or more photons are absorbed and a single quantum of energy is emitted, generating short wavelength light from long wavelength light [18-20]. The structure of UCNPs is a matrix of alkali metal compounds in which the respective lanthanide elements are embedded [21,22]. In UCNPs, lanthanide elements consist of a sensitizer that absorbs long wavelengths of light and an activator that emits short wavelengths of light. In particular, the core@shell structure that separates the activator and the sensitizer is widely used to maximize the fluorescence efficiency of UCNPs [23-26]. The clinical significance of UCNPs requires the strong permeability of NIR light because the absorption of biological window I (700-980 nm) light is low in the skin and body [27]. Consequently, UCNPs have been utilized as a light-generating source $(\sim 660 \mathrm{~nm})$ subsequent to their absorption of well-permeating NIR light (>800 $\mathrm{nm}$ ), which overcomes the limitation of triggering PS in the body [28-31].

Herein, we sought to design and prepare highly red fluorescence light-emitting core-shell upconverting nanoparticles surface-modified with silica, followed by PEG-folic acid (FA/PEG) and TCPP (UCNPs@SiO $2-\mathrm{NH}_{2} @ \mathrm{FA} / \mathrm{PEG} / \mathrm{TCPP}$ ), as an efficient photodynamic agent for killing tumor cells. The UCNPs@SiO $-\mathrm{NH}_{2} @ \mathrm{FA} / \mathrm{PEG} / \mathrm{TCPP}$ was fabricated in a core-shell structure by doping with erbium/lutetium to mainly emit $\sim 660 \mathrm{~nm}$ to activate the adjoining TCPP, and the folic acid ligand was conjugated as a targeting moiety of HeLa cells. Analytical/morphological investigations to identify the UCNPs@SiO $\mathrm{S}_{2}-\mathrm{NH}_{2} @ \mathrm{FA} / \mathrm{PEG} / \mathrm{TCPP}$ in vitro cytotoxicity were conducted to evaluate the antitumor potential, and an evaluation of the UCNP penetration in HeLa cell spheroids was conducted to achieve this aim (Figure 1). 


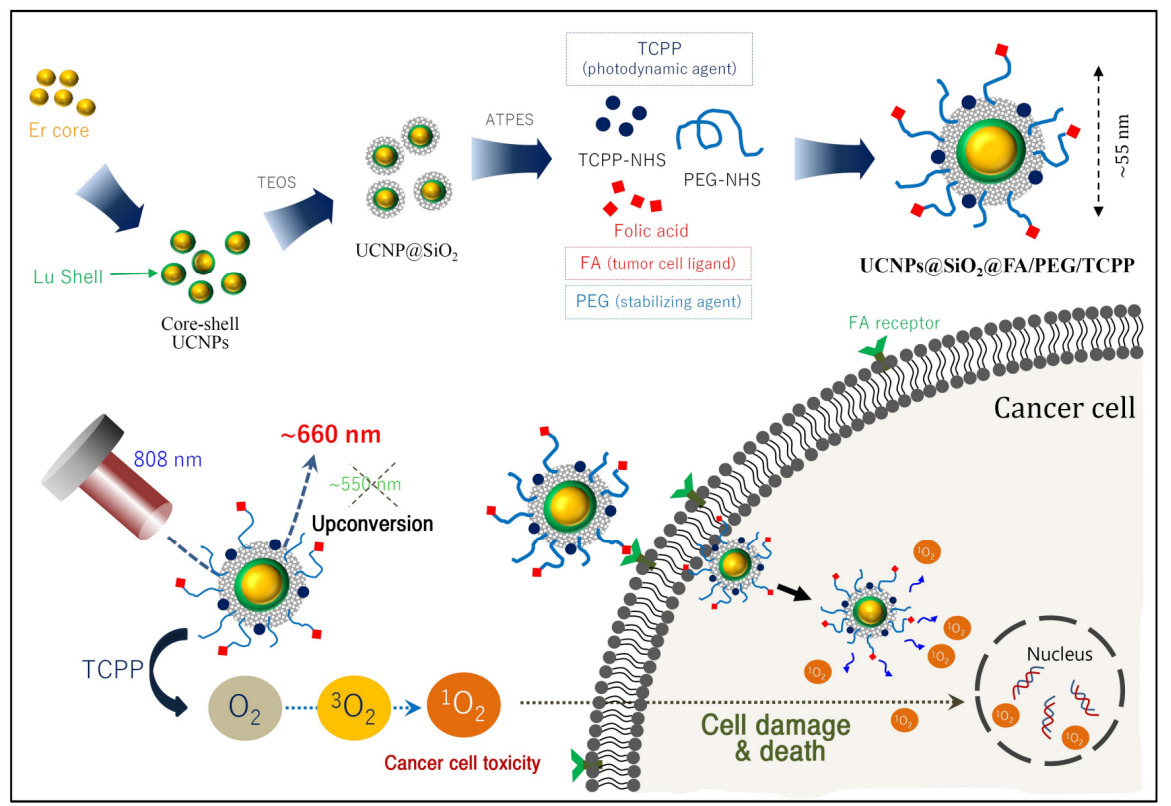

Figure 1. Schematic illustration of the preparation of core-shell upconverting nanoparticles surface-modified with silica, PEG-folic acid (FA/PEG), and TCPP (UCNPs@SiO ${ }_{2} @$ FA/PEG/TCPP) for photodynamic therapy based on singlet oxygen generation.

\section{Materials and Methods}

\subsection{Materials}

Erbium(III) acetate hydrate, lutetium(III) acetate hydrate, yttrium(III) acetate hydrate, ytterbium(III) acetate hydrate, neodymium(III) acetate hydrate, ammonium fluoride $\left(\mathrm{NH}_{4} \mathrm{~F}\right)$, oleic acid $(90 \%)$, 1-octadecene $(90 \%)$, IGEPAL ${ }^{\circledR}$ CO-520, and ammonium hydroxide solution (28-30\%) were purchased from Sigma-Aldrich (St. Louis, MO, USA). Tetraethyl orthosilicate (TEOS), 3-aminopropyltriethoxy-silane (APTES), and tetrakis(4-carboxyphenyl)porphyrin (TCPP) were purchased from Tokyo Chemical Industry (TCI) Co., Ltd. (Toshima, Kita-ku, Tokyo, Japan). $\mathrm{mPEG}_{2 \mathrm{k}}-\mathrm{SC}$ and FA/PEG $5 \mathrm{k}-\mathrm{NHS}$ were purchased from Biochempeg (Watertown, MA, USA). The HeLa (ATCC ${ }^{\circledR}$ CCL-2 ${ }^{\mathrm{TM}}$ ) human adenocarcinoma cell line was obtained from the American Type Culture Collection (Rockville, MD, USA). DMEM and fetal bovine serum (FBS) were purchased from Capricorn (Ebsdorfergrund, Hesse, Germany). Trypsin-EDTA and penicillin-streptomycin (P/S) solution were purchased from Corning (Corning, NY, USA). The LIVE/DEAD ${ }^{\mathrm{TM}}$ viability/cytotoxicity assay kit, LysoTracker ${ }^{\mathrm{TM}}$ Green DND-26, and singlet oxygen sensor green reagent (SOSG) were purchased from Thermo Fisher Scientific (Waltham, MA, USA). All other reagents were obtained from Sigma-Aldrich unless otherwise indicated.

\subsection{Synthesis of Core UCNPs for Red Emission}

Upconverting nanoparticles of $\sim 30 \mathrm{~nm}$ were manufactured by slight modification of an existing procedure [32-37]. Briefly, $3 \mathrm{mmol}$ of $\mathrm{Er}\left(\mathrm{CH}_{3} \mathrm{CO}_{2}\right)_{3}$ in $5 \mathrm{~mL}$ of methanol was added to a round bottom flask containing $12 \mathrm{~mL}$ of oleic acid (OA) and $45 \mathrm{~mL}$ of octadecene (ODE). Methanol was evaporated at $110{ }^{\circ} \mathrm{C}$ under vacuum for $20 \mathrm{~min}$, and the reaction temperature was maintained at $150{ }^{\circ} \mathrm{C}$ for $1 \mathrm{~h}$ under argon flow to obtain a clear solution. After cooling, methanol solution containing $12 \mathrm{mmol}$ $\mathrm{NH}_{4} \mathrm{~F}$ and $7.5 \mathrm{mmol} \mathrm{NaOH}$ was added slowly to the reaction vessel and kept at $50{ }^{\circ} \mathrm{C}$ for $30 \mathrm{~min}$. After removing methanol using the same evaporation process, the vessel was heated to $310{ }^{\circ} \mathrm{C}$ at the rate of $10-15^{\circ} \mathrm{C} / \mathrm{min}$ and maintained at this temperature for 90 min under an argon atmosphere. The mixture was cooled to room temperature, and an equal volume of acetone was added to precipitate the product UCNPs. The resulting suspension was centrifuged at $6554 \mathrm{~g}$ for $10 \mathrm{~min}$. The pellet was 
collected and redispersed in $20 \mathrm{~mL}$ of $\mathrm{n}$-hexane. This mixture was centrifuged at $1000 \mathrm{~g}$ for $5 \mathrm{~min}$ to remove large particles. Finally, the supernatant containing fine UCNPs was harvested and placed in storage at $4-8{ }^{\circ} \mathrm{C}$ for further experiments.

\subsection{Synthesis of Core-Shell UCNPs for Red Emission}

The core-shell upconverting nanoparticles were prepared by slight modification of a procedure described elsewhere [37]. Briefly, $1 \mathrm{mmol}$ of $\mathrm{Lu}\left(\mathrm{CH}_{3} \mathrm{CO}_{2}\right)_{3}$ in $2 \mathrm{~mL}$ of methanol was added to the round bottom flask containing $8 \mathrm{~mL}$ of OA and $30 \mathrm{~mL}$ of ODE. Methanol was evaporated at $110{ }^{\circ} \mathrm{C}$ under vacuum for $10 \mathrm{~min}$, and the temperature was maintained at $150{ }^{\circ} \mathrm{C}$ for $1 \mathrm{~h}$ under argon flow to obtain a clear solution. After cooling, $225 \mathrm{mg}$ of the as-synthesized core UCNPs in n-hexane was added to the solution and heated to $110^{\circ} \mathrm{C}$ for $30 \mathrm{~min}$ under vacuum to remove $\mathrm{n}$-hexane. The temperature was decreased to $50{ }^{\circ} \mathrm{C}$ prior to the slow addition of $4 \mathrm{mmol} \mathrm{NH}_{4} \mathrm{~F}$ and $2.5 \mathrm{mmol} \mathrm{NaOH}$ in methanol. After a $30 \mathrm{~min}$ incubation period at $50{ }^{\circ} \mathrm{C}$, methanol was evaporated using the process described above. Next, the reaction vessel was heated to $310^{\circ} \mathrm{C}$ at a rate of $10-15^{\circ} \mathrm{C} / \mathrm{min}$ and maintained at this temperature for $90 \mathrm{~min}$ under an argon atmosphere. The mixture was cooled to room temperature, and an equal volume of acetone was added to precipitate UCNPs. The resulting suspension was centrifuged at $6554 \mathrm{~g}$ for $10 \mathrm{~min}$. The pellet was collected and redispersed in $20 \mathrm{~mL}$ of hexane. This mixture was centrifuged at $1000 \mathrm{~g}$ for $5 \mathrm{~min}$ to remove large particles. Finally, the supernatant containing fine UCNPs was harvested and placed in storage at $4-8{ }^{\circ} \mathrm{C}$ for further studies.

\subsection{Synthesis of Core@shell Upconverting Nanoparticles (UCNPs) for Green Emission}

For the UCNP core structure, $3 \mathrm{mmol}$ each of $\mathrm{Y}\left(\mathrm{CH}_{3} \mathrm{CO}_{2}\right)_{3}, \mathrm{Yb}\left(\mathrm{CH}_{3} \mathrm{CO}_{2}\right)_{3}, \operatorname{Er}\left(\mathrm{CH}_{3} \mathrm{CO}_{2}\right)_{3}$, and $\mathrm{Nd}\left(\mathrm{CH}_{3} \mathrm{CO}_{2}\right)_{3}$ [by molar ratio, $68.5 \% \mathrm{Y}, 30 \% \mathrm{Yb}, 0.5 \% \mathrm{Er}, 1 \% \mathrm{Nd}$ ] was dissolved in $5 \mathrm{~mL}$ methanol. The core synthesis process is the same as that described above. All remaining steps were performed according to the same procedure used for the synthesis of the regular core UCNP structure described above. For the UCNP shell structure, $1 \mathrm{mmol}$ each of $\mathrm{Y}\left(\mathrm{CH}_{3} \mathrm{CO}_{2}\right)_{3}$ and $\mathrm{Nd}\left(\mathrm{CH}_{3} \mathrm{CO}_{2}\right)_{3}$ [by molar ratio, $80 \% \mathrm{Y}, 20 \% \mathrm{Nd}$ ] was dissolved in $2 \mathrm{~mL}$ methanol. All remaining steps are the same as those used for the synthesis of the regular shell UCNP structure described above [35,38].

\subsection{Surface Modification of UCNPS}

Amine-functionalized UCNPs (UCNPs@SiO ${ }_{2}-\mathrm{NH}_{2}$ ) were prepared through a series of steps described elsewhere [39]. A portion $(25 \mathrm{~mL})$ of UCNP solution $(2 \mathrm{mg} / \mathrm{mL}$ in hexane) was mixed with $1200 \mathrm{mg}$ of IGEPAL ${ }^{\circledR}$ CO-520 in an ultrasound bath. A $200 \mu \mathrm{L}$ aliquot of ammonium hydroxide solution $(30 \%)$ was added to the mixture and gently shaken. The reaction started by the addition of TEOS $(150 \mu \mathrm{L}, 0.7 \mathrm{mmol})$ under stirring and continued overnight at room temperature. The resulting UCNPs@SiO ${ }_{2}$ was purified by centrifugation with ethanol $(3 \times 8500 \mathrm{rpm}, 10 \mathrm{~min})$. Amino groups on UCNPs@SiO 2 were functionalized with APTES $(750 \mu \mathrm{L}, 3.4 \mathrm{mmol})$ in $25 \mathrm{~mL}$ of ethanol. This mixture was stirred overnight at room temperature. The UCNPs@SiO ${ }_{2}-\mathrm{NH}_{2}$ nanoparticle fraction was centrifuged $(3 \times 8500 \mathrm{rpm}, 10 \mathrm{~min})$, harvested, and redispersed in $25 \mathrm{~mL}$ distilled water (DW).

\subsection{Preparation of UCNPs@SiO $-\mathrm{NH}_{2} @ F A / P E G / T C P P$}

UCNPs@SiO ${ }_{2}-\mathrm{NH}_{2}$ was conjugated with TCPP, $\mathrm{mPEG}_{2 \mathrm{k}}-\mathrm{SC}-\mathrm{NHS}$, and FA/PEG $5 \mathrm{k}-\mathrm{NHS}$ using a slight modification of the procedure described elsewhere [40,41]. To synthesize TCPP-NHS, TCPP (0.2 mmol), N-dicyclohexylcarbodiimide (DCC, $0.3 \mathrm{mmol}), \mathrm{N}$-hydroxysuccinimide (NHS, $0.3 \mathrm{mmol}$ ), and triethylamine (TEA, $0.3 \mathrm{mmol}$ ) were mixed in $5.3 \mathrm{~mL}$ dimethyl sulfoxide (DMSO), and the reaction was allowed to continue in the dark for $24 \mathrm{~h}[2,42]$. After removing the precipitate of DCU, the product was stored at $-80{ }^{\circ} \mathrm{C}$. UCNPs@SiO ${ }_{2}-\mathrm{NH}_{2}(10 \mathrm{mg}), \mathrm{FA} / \mathrm{PEG}_{5 \mathrm{k}}-\mathrm{NHS}(0.1 \mathrm{mg})$, and TCPP-NHS (1 mg) were mixed in PBS (pH 8.0). After $1 \mathrm{~h}, \mathrm{mPEG}_{2 \mathrm{k}}-\mathrm{SC}(2 \mathrm{mg})$ was added to the resulting solution and stirred for $12 \mathrm{~h}$. The mixture was centrifuged ( $8500 \mathrm{rpm}, 20 \mathrm{~min}$ ) and redispersed in DW. 


\subsection{Characterization of Various UCNPS}

The particle size of a series of UCNPs was determined by dynamic light scattering (DLS) (Zetasizer Nano-S90, Malvern Instruments Ltd., Worcestershire, UK) at a $90^{\circ}$ scattering angle. Irradiation by an $808 \mathrm{~nm}$ laser (Laserlab CO, Gyeonggi-do, Korea) was used to identify the fluorescence emission of UCNPs. The morphology of UCNPs was examined using an ultrahigh-resolution analytical electron microscope (HR-TEM) (JEM-3010, JEOL Ltd., Tokyo, Japan). A multimode microplate reader (Synergy $^{\mathrm{TM}}$ Neo2, BioTek Instruments, Winooski, VT, USA) was used for the UV-Vis-NIR analysis of the core and shell structures.

\subsection{Singlet Oxygen Generation of UCNPs@SiO $2-\mathrm{NH}_{2} @ F A / P E G / T C P P$}

Singlet oxygen sensor green (SOSG) reagents were used to determine the singlet oxygen generation from UCNPs@SiO $2-\mathrm{NH}_{2} @ \mathrm{FA} / \mathrm{PEG} / \mathrm{TCPP}[2,43]$. Aliquots (2 mL) of samples of DW, free TCPP, UCNPs@SiO ${ }_{2}-\mathrm{NH}_{2} @ \mathrm{FA} / \mathrm{PEG}$, and UCNPs@SiO $2-\mathrm{NH}_{2} @ \mathrm{FA} / \mathrm{PEG} / \mathrm{TCPP}$ were mixed with the SOSG reagents (final concentration: $2.5 \mu \mathrm{M})$ in a 24-well plate. An $808 \mathrm{~nm}$ laser $\left(1.5 \mathrm{~W} / \mathrm{cm}^{2}\right)$ irradiated the respective sample wells for DW, UCNPs@SiO $2-\mathrm{NH}_{2} @ \mathrm{FA} / \mathrm{PEG}$, and UCNPs@SiO $-\mathrm{NH}_{2} @ \mathrm{FA} / \mathrm{PEG} / \mathrm{TCPP}$, and a $660 \mathrm{~nm}$ laser $\left(10 \mathrm{~mW} / \mathrm{cm}^{2}\right)$ was used for free TCPP. While irradiating the laser for $60 \mathrm{~min}$, a $100 \mu \mathrm{L}$ aliquot of each sample was collected every $10 \mathrm{~min}$, and the fluorescence intensities were determined using a multimode microplate reader (excitation: $485 \mathrm{~nm}$, emission: $538 \mathrm{~nm}$ ).

\subsection{Cytotoxicity Evaluation of UCNPs@SiO $-\mathrm{NH}_{2} @ F A / P E G / T C P P$}

The cytotoxicity of a series of UCNPs was evaluated by an MTT and a Live/Dead viability assay kit in HeLa cells using a slightly modified previously described procedure [44-46]. For the MTT assay, $100 \mu \mathrm{L}$ of HeLa cancer cells $\left(1 \times 10^{5}\right.$ cells $\left./ \mathrm{mL}\right)$ was seeded into the wells of a 96-well plate (SPL Life Sciences CO., LTD) and incubated for $24 \mathrm{~h}$. The HeLa cells were treated with each UCNP sample $(0,1$, $5,10,20,30 \mu \mathrm{g} / \mathrm{mL}$ as a free TCPP) in DMEM containing 1\% FBS and 1\% P/S. The concentration of conjugated TCPP onto UCNPs was determined at $660 \mathrm{~nm}$ using a UV-Vis spectrometer VersaMax $^{\mathrm{TM}}$ microplate reader, Molecular Devices, CA, USA) because the TCPP absorbance (660 nm) was not overlapped with those of UCNPs alone and folic acid. After a 4-h incubation, cells were rinsed twice and replenished with fresh DMEM. Hypoxic conditions were obtained by incubating in a hypoxic chamber $\left(5 \% \mathrm{CO}_{2}, 95 \% \mathrm{~N}_{2}\right)$ for $4 \mathrm{~h}$. Each sample was irradiated with a $660 \mathrm{~nm}$ laser $\left(10 \mathrm{~mW} / \mathrm{cm}^{2}\right)$ or $808 \mathrm{~nm}$ laser $\left(1.5 \mathrm{~W} / \mathrm{cm}^{2}\right)$ for $30 \mathrm{~min}$ and then incubated for $24 \mathrm{~h}$. After a treatment with $0.5 \mathrm{mg} / \mathrm{mL}$ of MTT reagents for $2 \mathrm{~h}$, MTT reagents were removed, and $100 \mu \mathrm{L}$ of dimethyl sulfoxide (DMSO) was added for $20 \mathrm{~min}$. Finally, the absorbance intensity at $562 \mathrm{~nm}$ was analyzed using a UV-Vis spectrometer.

Live/Dead ${ }^{\mathrm{TM}}$ viability/cytotoxicity kits were used to visualize the death and viability of HeLa cells. For this, $100 \mu \mathrm{L}$ of HeLa cancer cells $\left(1 \times 10^{5}\right.$ cells/mL) was seeded in a 12 -well plate (Ibidi, Lochhamer, Germany) and further incubated for $24 \mathrm{~h}$. The subsequent steps were performed according to the same protocol as for the MTT assay. At $24 \mathrm{~h}$ after laser irradiation, cells were washed with PBS twice and stained with Live/Dead assay solution ( $4 \mathrm{~mL}$ of PBS, $8 \mu \mathrm{L}$ of ethidium homodimer-1, $2 \mu \mathrm{L}$ of calcein-AM) for $30 \mathrm{~min}$. Stained cells were observed using a confocal laser scanning microscope (CLSM) (LSM510, Carl Zeiss Meditec AG, Jena, Germany).

\subsection{Cellular Uptake of UCNPs in HeLa Cells and Spheroids}

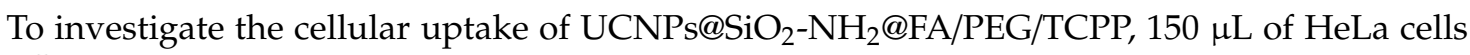
$\left(1 \times 10^{5}\right.$ cells $\left./ \mathrm{mL}\right)$ was seeded in an 8 -well plate (Ibidi, Lochhamer, Germany) and incubated for $24 \mathrm{~h}$ [46]. HeLa cells were treated with each UCNP sample $(20 \mu \mathrm{g} / \mathrm{mL}$ as a free TCPP). At predetermined time points $(10,20,30$, and $60 \mathrm{~min})$, cells were washed three times with PBS and stained with LysoTracker ${ }^{\mathrm{TM}}$ Green and DAPI $[47,48]$. The cells were observed using a CLSM (excitation of TCPP: $633 \mathrm{~nm}$, emission of TCPP: 650-680 nm) [49]. Separately, the internalization of UCNPs@SiO $\mathrm{SH}_{2} @ \mathrm{FA} / \mathrm{PEG} / \mathrm{TCPP}$ was evaluated in three-dimensional HeLa cell spheroids $[2,45,46]$. 
Aliquots $(100 \mu \mathrm{L})$ of HeLa cells $\left(3 \times 10^{4}\right.$ cells/mL) in DMEM (containing $\left.1 \% \mathrm{FBS}, 1 \% \mathrm{P} / \mathrm{S}\right)$ were seeded in V-shaped 96-well plates designed to induce the formation of 3D multicellular spheroids (Shimadzu Scientific Instruments, Kyoto, Japan) and incubated for $36 \mathrm{~h}$. The cell spheroids were treated with UCNPs@SiO ${ }_{2}-\mathrm{NH}_{2} @$ FA/PEG/TCPP $(30 \mu \mathrm{g} / \mathrm{mL}$ of TCPP). After a 24-h incubation, the spheroids were transferred to an 8-well plate with PBS, and cells were observed using a CLSM.

\subsection{Data Analysis}

Data are presented as the mean \pm standard deviation (SD). The significance of differences was determined by a Student's $t$-test. $p$-values $<0.05$ were considered statistically significant.

\section{Results and Discussion}

\subsection{Synthesis and Characterization of Core@shell UCNPs}

The conventional UCNPs doped with the core or shell element of yttrium (Y), ytterbium (Yb), and neodymium (Nd) have split fluorescence lights of $\sim 545 \mathrm{~nm}$ and $660 \mathrm{~nm}$, which is considered to be a main reason for a reduced PDT efficiency [37]. To this end, the first specific aim of this study was to develop a prototype of UCNPs@SiO 2 that emitted $\sim 660 \mathrm{~nm}$ red light and was surface-modified with folic acid for an efficient PDT treatment. As a first step, we aimed to produce a hexagonal core of UCNPs to achieve optimal fluorescence efficacy values [50]. As shown in Figure 2A, changing the molar ratio of OA and ODE resulted in a significant morphological change of core UCNPs: the core UCNPs were spherical at a ratio of 3:7 but had sharpened edges and exhibited an optimal hexagonal shape at a ratio of 4:15. Therefore, this ratio was chosen for the core UCNPs.
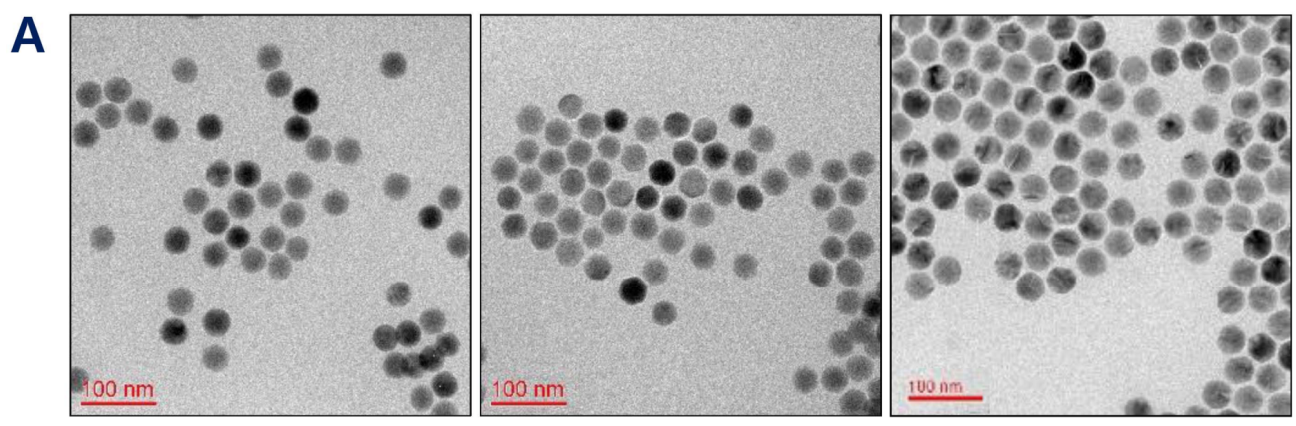

B
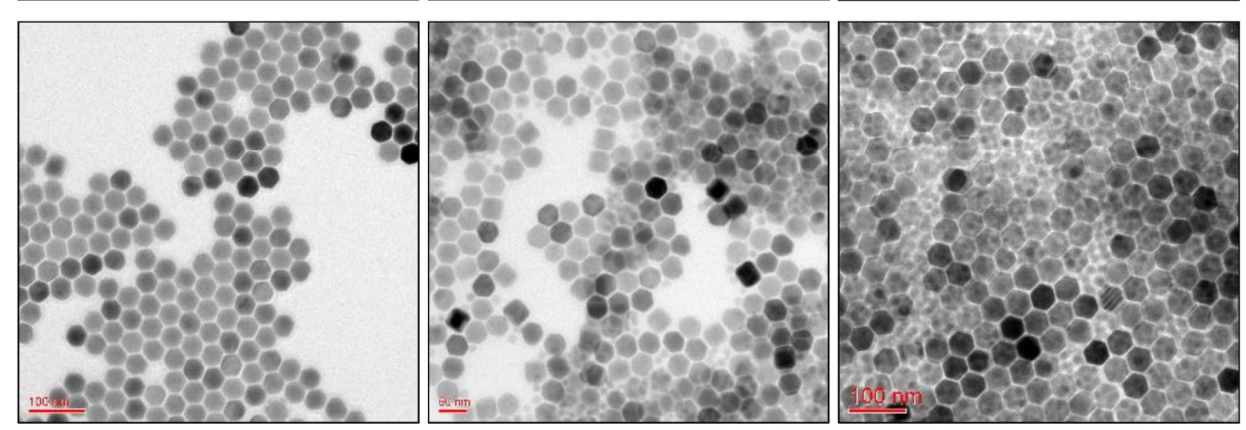

Figure 2. (A) TEM images of UCNPs depending upon the ratio between oleic acid (OA) and 1-octadecene (ODE) (3:7 for left, 6:15 for middle, and 4:15 for right). (B) TEM images of core@shell UCNPs depending upon the molar ratio between the core (erbium) and shell (lutetium) components (1:0.5 for left, 1:1 for middle, and 1:1.5 for right).

The surface characteristics of UCNPs are of prime importance because lanthanide-doped core-only UCNPs have a relatively weak upconverting efficiency. Among several methods, the utilization of a core/shell structure is considered the most effective for enhancing the efficiency [14]. The shells of UCNPs were made of lutetium using $\mathrm{Lu}\left(\mathrm{CH}_{3} \mathrm{CO}_{2}\right)_{3}$ to produce UCNPs with a red fluorescence. 
At molar ratios (core to shell $=\mathrm{Er}\left(\mathrm{CH}_{3} \mathrm{CO}_{2}\right)_{3}$ to $\left.\mathrm{Lu}\left(\mathrm{CH}_{3} \mathrm{CO}_{2}\right)_{3}\right)$ of 1:0.5, 1:1, and 1:1.5, the morphologies of core@shell UCNPs were observed by TEM. Increasing the lutetium amount led to a size increase of core@shell UCNPs. However, the empty shell debris not attached to the surface of core@shell UCNPs was shown at ratios $>1: 1$, presumably due to excess lutetium shell material. This debris resulted in an inappropriate overall shape for further preparation. Based on the core@shell structure and size distribution, UCNPs were most uniform at a core to shell ratio of 1:0.5 (core:shell) (Figure 2B). The results of HR-TEM and dynamic light scattering (DLS) showed that the particle sizes for the core and core@shell of UCNPs were $28.4 \pm 6.0 \mathrm{~nm}$ and $33.6 \pm 7.7 \mathrm{~nm}$, respectively (Figure 3A,B). The size increase at each step of the core, shell, and silica layer indicated that our UCNPs were well-doped and well-coated with $\mathrm{Er}, \mathrm{Lu}$, and $\mathrm{SiO}_{2}$ and that this unique structure would play a critical role in photodynamic therapy and tumor recognition.
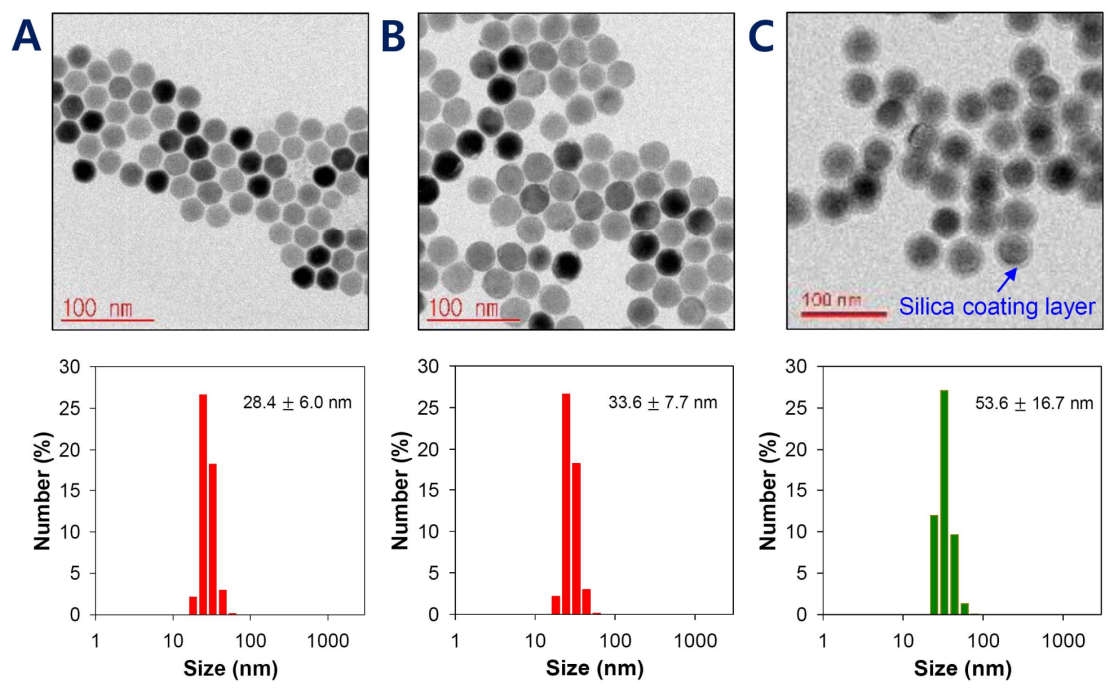

Figure 3. HR-TEM images and histograms of the particle size of (A) core-only UCNPs, (B) core@shell UCNPs, and (C) core@shell UCNPs@SiO . Data are presented as means \pm SDs $(n=3)$.

\subsection{Surface Modification of Core@shell UCNPs}

The physical stability of UCNPs was a critical consideration in targeting ligand conjugation and further drug delivery because lanthanide-doped and oleate-capped UCNPs are hydrophobic and weakly water-dispersible [51,52]. Therefore, the hydrophilic surface modification of such UCNPs is essential for subsequent pharmaceutical stability and biomedical applications [52]. Many methods have been utilized to achieve a hydrophilic UCNP surface by $\mathrm{NOBF}_{4}$-(nitrosonium tetrafluoroborate)-based two-step exchange using various ligands, such as bisphosphonoglycine, citrate, polyacrylic acid (PAA), polyethylene glycol, and polyallylamine (PAAm) [51]. In this study, silica coating is considered the most useful method to address the surface hydrophobicity of UCNPs and to provide an advantage for further conjugation steps. The silica layer converts hydrophobic UCNPs to hydrophilic/dispersible UCNPs in aqueous media. It is also easily modified with various chemical groups (e.g., $-\mathrm{COOH}$, $\left.-\mathrm{NH}_{2},-\mathrm{SH}\right)$ that provide conjugation with functional agents or biological molecules $[39,53,54]$. To introduce a silica layer on the UCNPs, the well-established reverse micelle method was used: $\mathrm{SiO}_{2}$ grew on the surface of Igepal-stabilized UCNPs via the ammonia-catalyzed polymerization of TEOS [54]. The thickness of the silica coating layer was about $10 \mathrm{~nm}$, showing a total size of $53.6 \pm 16.7 \mathrm{~nm}$ for core@shell-UCNP@SiO 2 , an increase of $20 \mathrm{~nm}$ over the prior step (Figure 3C). Additionally, the resulting size of core@shell-UCNP@SiO 2 appeared to have the potential for tumor accumulation because nanoparticles of 50-100 nm have a high tumor targetability [55,56].

UCNPs absorb light in the infrared region and emit light in various visible regions, which enables their application to PDT $[40,41]$, PTT $[57,58]$, and bioimaging $[17,59,60]$. For PDT using porphyrin 
ring structured PS in particular, it is of prime importance that UCNPs absorb long wavelength light $(\sim 800 \mathrm{~nm})$ and maximize the fluorescence efficiency of red light $(600-700 \mathrm{~nm})$, since most PS are activated near $660 \mathrm{~nm}$ in the red region. Conventional UCNPs made use of lanthanide elements $(\mathrm{Y}, \mathrm{Yb}$, $\mathrm{Er}$, and $\mathrm{Nd}$ ) that showed a strong emission of green light (Figure 4A). Green fluorescence is more applicable to bioimaging than to PDT. In contrast, our simple UCNPs made of the Er core and Lu shell displayed a strong red fluorescence light emission (Figure 4B). Furthermore, this red light was maintained significantly despite the $10 \mathrm{~nm}$ silica coating layer. In agreement with a previous result by He et al. [37], this ability of the core@shell UCNPs might enable the unambiguous strengthening of the PDT effect of TCPP. Likewise, core@shell UCNPs showed peak absorption at around 800 nm NIR light, which was much greater than that of core-only UCNPs, indicating the importance of the lutetium shell (Figure 5A). The result obviously suggested that these UCNPs would have a great effectiveness in generating the relevant light $(\sim 660 \mathrm{~nm})$ that is useful for further in vivo PDT, accompanied by the irradiation of the deep-penetrating $808 \mathrm{~nm}$ NIR laser.

\subsection{Preparation and Characterization of UCNPs@SiO $@ @ F A / P E G / T C P P$}

The surface hydroxyl group $(-\mathrm{OH})$ in $\mathrm{UCNPs} @ \mathrm{SiO}_{2}$ was replaced with an amino group $\left(-\mathrm{NH}_{2}\right)$ by adding APTES, which was a preliminary step to conjugation with TCPP-NHS, PEG $2 \mathrm{k}-\mathrm{NHS}_{\text {, }}$ and FA/PEG $5 \mathrm{k}-\mathrm{NHS}$. A 5k length (molecular weight-based) of folic acid-PEG was chosen as it was longer than naïve PEG (2k) (present solely as a dispersing stabilizer) to locate at the outermost surface of UCNPs. To overcome these problems, we developed UCNPs@SiO $\mathrm{NH}_{2} @ \mathrm{FA} / \mathrm{PEG} / \mathrm{TCPP}$ conjugates. The use of UCNPs solved the problem of skin permeability, and PEG could overcome the poor solubility of TCPP $[29,30,61]$. In addition, the targetability of nanoparticles was increased by the conjugation of folic acid [62]. Folic acid is a member of the B vitamin group, and various cancer cells, such as those of ovarian and cervical cancer, express folic acid receptors [63,64]. When folic acid is conjugated to nanoparticles, the endocytosis process can increase the rate of absorption into the tumor [62].

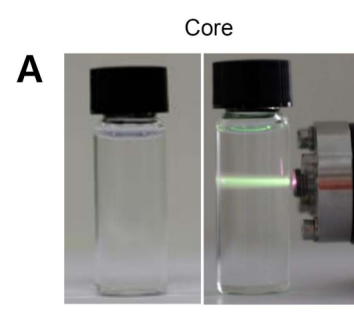

Core
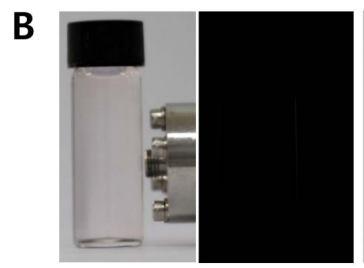

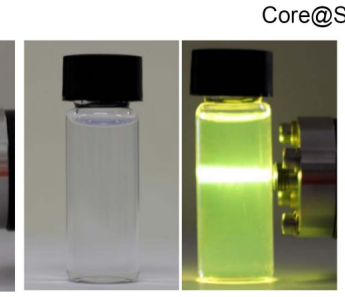

Core@Shell

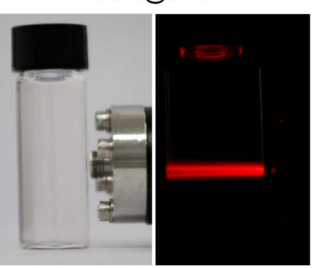

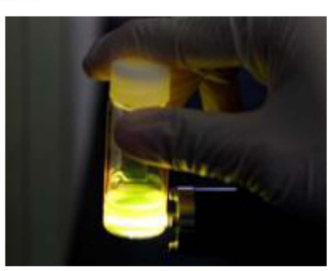

Core@Shell@SiO

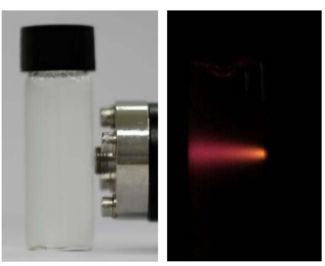

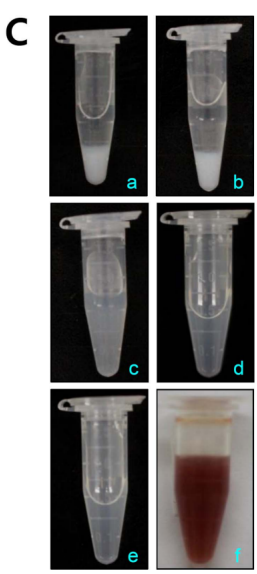

Figure 4. (A) Photographs of core or core@shell upconverting nanoparticles (UCNPs) emitting green fluorescence. (B) Photographs of core, core@shell, or core@shell@ $\mathrm{SiO}_{2} \mathrm{UCNPs}$ emitting red fluorescence. (C) Photo images of silica-coated upconverting nanoparticles (UCNPs@SiO 2$)(10 \mathrm{mg})$ modified with (a) mPEG (0.1 mg) and FA/PEG (0.1 mg); (b) mPEG (0.2 mg) and FA/PEG (0.1 mg); (c) mPEG (0.5 mg) and FA/PEG (0.1 mg); (d) mPEG (1.0 mg) and FA/PEG (0.1 mg); (e) mPEG (2.0 mg) and FA/PEG (0.1 mg); and (f) $\mathrm{mPEG}(2.0 \mathrm{mg})$, FA/PEG (0.1 mg), and TCPP (1.0 mg).

As shown in Figure 5B, amine group introduction in $\mathrm{UCNPs}_{\mathrm{S}} \mathrm{SiO}_{2}$ resulted in a zeta potential change from -29.8 to $+10.1 \mathrm{mV}$. However, the UCNPs@SiO $2-\mathrm{NH}_{2}$ tended to aggregate due to its relatively weak charges, and naïve PEG and FA/PEG were quickly conjugated to UCNPs@SiO $-\mathrm{NH}_{2}$.

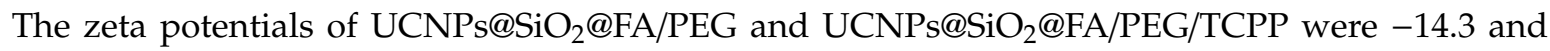
$-34.5 \mathrm{mV}$, respectively (Figure 5B). As shown in Figure $4 \mathrm{C}$, the increase in the feed amount of 
naïve $\mathrm{PEG}_{2 \mathrm{k}}\left(0.1-2.0 \mathrm{mg}\right.$ to $\left.10 \mathrm{mg} \mathrm{UCNPs} @ \mathrm{SiO}_{2}\right)$ showed a clearly improved dispersibility of the relevant UCNPs@SiO 2 : UCNPs@SiO 2 precipitated in aqueous media at a $\mathrm{PEG}_{2 \mathrm{k}}$ amount of 0.1-0.2 mg, whereas UCNPs@SiO 2 was very stable and dispersible at a $\mathrm{PEG}_{2 \mathrm{k}}$ amount of 1-2 mg despite the presence of hydrophobic folic acid and TCPP. This is a clear pharmaceutical advantage of

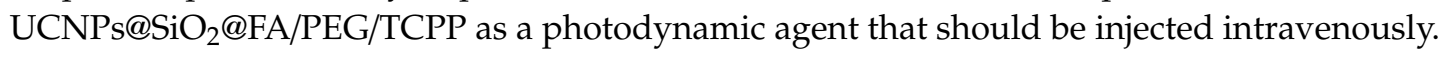

Multimode UV spectrophotometry was used to measure the absorbance profiles between 450 and $750 \mathrm{~nm}$ for free TCPP, UCNPs@SiO $2-\mathrm{NH}_{2} @ \mathrm{FA} / \mathrm{PEG}$, and UCNPs@SiO $-\mathrm{NH}_{2} @ \mathrm{FA} / \mathrm{PEG} / \mathrm{TCPP}$. As shown in Figure 5C, UCNPs@SiO $-\mathrm{NH}_{2} @ \mathrm{FA} / \mathrm{PEG} / \mathrm{TCPP}$ has a significant absorption peak around $660 \mathrm{~nm}$, a common feature of TCPP [43]. On the contrary, UCNPs@SiO $-\mathrm{NH}_{2} @ \mathrm{FA} / \mathrm{PEG}$ without TCPP conjugation had no absorption peak from 450 to $750 \mathrm{~nm}$, showing an almost flat spectrum. The results suggest that UCNPs@SiO $2-\mathrm{NH}_{2} @ \mathrm{FA} / \mathrm{PEG} / \mathrm{TCPP}$ would produce a cancer cell death effect by the photodynamic mode.
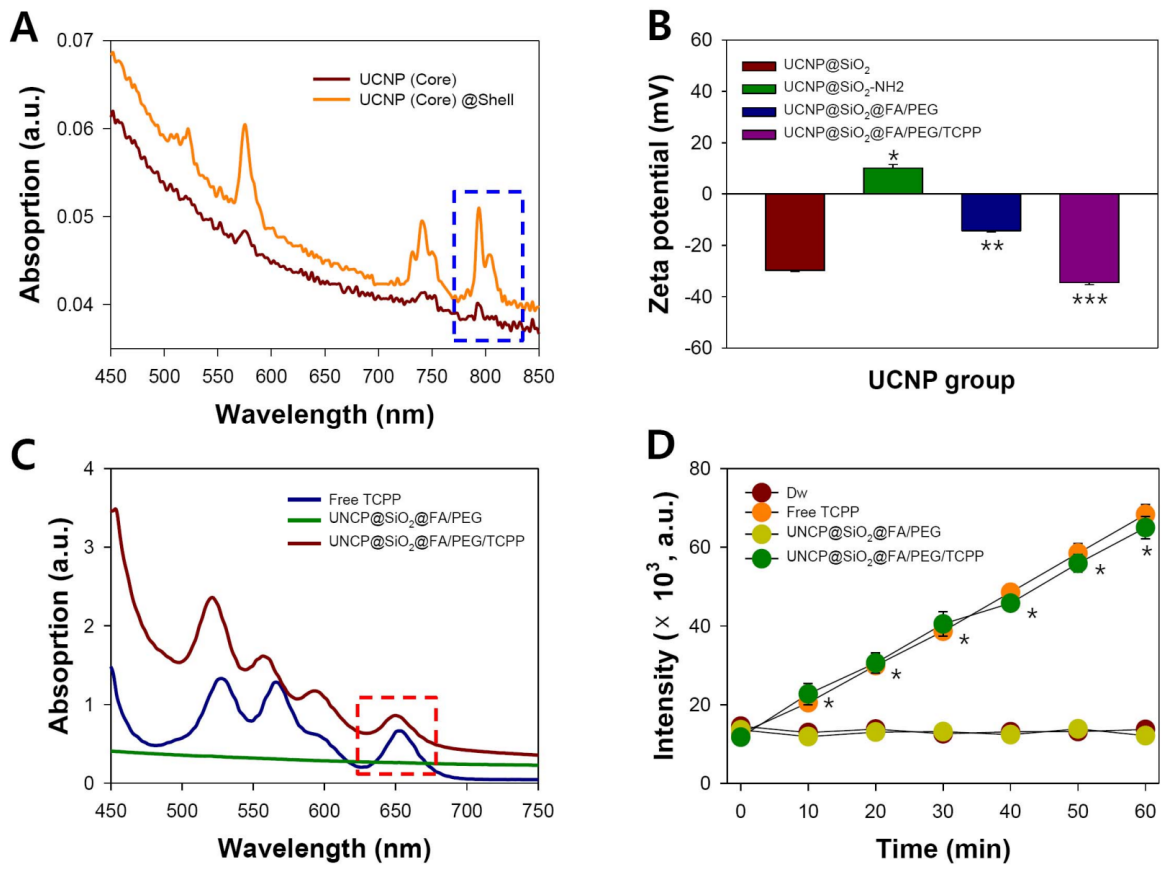

Figure 5. (A) UV-Vis-NIR absorption spectra of core and core@shell UCNPs (400-850 nm). (B) Zeta

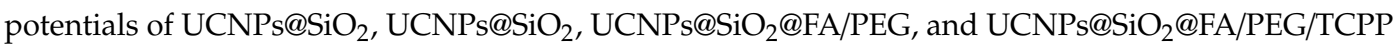

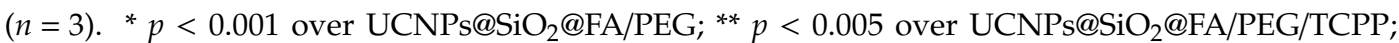
*** $p<0.005$ over UCNPs@SiO ${ }_{2} @$ FA/PEG. (C) UV-Vis-NIR absorption spectra $(450-750 \mathrm{~nm})$ and (D) singlet oxygen generation assay of DW, free TCPP, UCNPs@SiO $@$ FA/PEG, and UCNPs@SiO $@$ @FA/PEG/TCPP (DW: 808 nm, $1.5 \mathrm{~W} / \mathrm{cm}^{2}$; free TCPP: $0.5 \mu \mathrm{g} / \mathrm{mL}, 660 \mathrm{~nm}, 10 \mathrm{~mW} / \mathrm{cm}^{2}$;

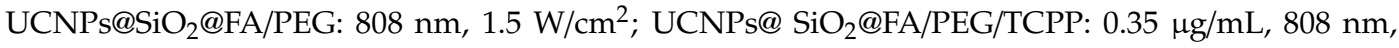
$\left.1.5 \mathrm{~W} / \mathrm{cm}^{2}\right)(n=3) .{ }^{*} p<0.001$ over Dw and UCNPs@SiO ${ }_{2} @ \mathrm{FA} / \mathrm{PEG}$.

\subsection{Singlet Oxygen Generation Assay of TCPP Conjugates}

PDT has been considered an effective means of inducing cancer cell death $[2,8,65]$. To date, several photodynamic therapeutics, such as Photofrin ${ }^{\circledR}$, Ameluz $^{\circledR}$, Metvix ${ }^{\circledR}$, Foscan ${ }^{\circledR}$, Laserphyrin ${ }^{\circledR}$, Visudyne ${ }^{\circledR}$, and Redporfin ${ }^{\circledR}$, have been clinically approved for treating cancers and other indications [66]. Most PDT agents are based on second-generation PS like porphyrin and chlorin, which are more effective, technically superior, and responsive to light of 600-700 nm, with the exception of Visudyne ${ }^{\circledR}$. In our study, TCPP, a derivative of porphyrin, was chosen as a PS surface-modified with UCNPs because it had a good cellular uptake and water solubility [67], whereas many PS show physical aggregation and in vivo delivery problems due to a strong hydrophobicity. By virtue of these 
properties, TCPP presents an excellent photo-cytotoxicity for treating and visualizing tumors [68] and absorbs $\sim 660-670 \mathrm{~nm}$ light emitted from erbium/lutetium-based UCNPs.

Singlet oxygen sensor green (SOSG) is a fluorescent reagent that is highly selective with singlet oxygen and not with hydroxyl radical or superoxide [2,43]. The generated ${ }^{1} \mathrm{O}_{2}$ causes SOSG to emit a high green fluorescence (maximum excitation/emission wavelengths $=\sim 504 / 525 \mathrm{~nm}$ ) by stopping the quenching process of internal electron transfer. In our study, singlet oxygen generation by respective samples was examined for $60 \mathrm{~min}$. In non-TCPP samples (DW and UCNPs@SiO $\mathrm{SHH}_{2} @ \mathrm{FA} / \mathrm{PEG}$ ), the SOSG fluorescence level was negligible at a very low value over $60 \mathrm{~min}$ (Figure 5D). On the contrary, UCNPs@SiO ${ }_{2}-\mathrm{NH}_{2} @ \mathrm{FA} / \mathrm{PEG} / \mathrm{TCPP}$ had almost the same singlet oxygen-generating activity as free TCPP at normalized concentrations of TCPP, and the SOSG fluorescence gradually increased in proportion to the laser irradiation time (Figure 5D). This result indicated that $\mathrm{UCNPs} @ \mathrm{SiO}_{2}-\mathrm{NH}_{2} @ \mathrm{FA} / \mathrm{PEG} / \mathrm{TCPP}$ efficiently absorbed $808 \mathrm{~nm}$ light and emitted $\sim 660 \mathrm{~nm}$ light that activated TCPP to form singlet oxygen. Once again, the efficiency of singlet oxygen generation appeared to be greatly reinforced by the unique ability of the $660 \mathrm{~nm}$-emitting UCNPs platform.

\subsection{Cytotoxicity Assay for Various UCNPs in Normoxic and Hypoxic Conditions}

The cytotoxicities of various UCNPs, including UCNPs@SiO ${ }_{2}-\mathrm{NH}_{2} @$ FA/PEG/TCPP, toward HeLa cells were evaluated through an MTT assay under normoxic and hypoxic conditions. HeLa cells were treated with different concentrations $(0,1,5,10,20,30 \mu \mathrm{g} / \mathrm{mL})$ of TCPP-containing samples that were previously normalized as free TCPP, and received 660 and $808 \mathrm{~nm}$ laser irradiation for free TCPP and UCNPs, respectively. As shown in Figure 6, in the absence of laser irradiation, all experimental groups showed a low cytotoxicity regardless of the TCPP concentration and oxygen presence. UCNPs@SiO $2-\mathrm{NH}_{2} @ \mathrm{FA} / \mathrm{PEG}$ (without TCPP) displayed an insignificant cytotoxicity either with or without $808 \mathrm{~nm}$ light regardless of oxygen due to no lack of singlet oxygen generation. However, UCNPs@SiO $\mathrm{SH}_{2}-\mathrm{NH}_{2} @ \mathrm{FA} / \mathrm{PEG} / \mathrm{TCPP}$ appeared to generate singlet oxygen due to a clear cytotoxicity. In fact, UCNPs@SiO ${ }_{2}-\mathrm{NH}_{2} @ \mathrm{FA} / \mathrm{PEG} / \mathrm{TCPP}$ killed $~ 80 \%$ of HeLa cells at $30 \mu \mathrm{g} / \mathrm{mL}$ under $808 \mathrm{~nm}$ laser irradiation. The overall cytotoxicity degree of UCNPs@SiO${ }_{2}-\mathrm{NH}_{2} @ \mathrm{FA} / \mathrm{PEG} / \mathrm{TCPP}$ plus the $808 \mathrm{~nm}$ laser was almost the same as that of free TCPP plus the $660 \mathrm{~nm}$ laser, which indicated the effective upconversion of our sample for tumor ablation. Nevertheless, the cytotoxicity of $\mathrm{UCNPs} @ \mathrm{SiO}_{2}-\mathrm{NH}_{2} @ \mathrm{FA} / \mathrm{PEG} / \mathrm{TCPP}(70 \%$ cell viability) was significantly reduced under hypoxic conditions.

\subsection{Live/Dead Assay for Various UCNPs in Normoxic and Hypoxic Conditions}

In live/dead assays, both seeded 2D monolayers and 3D spheroids of HCT 116 cells were treated with PBS, free TCPP, and UCNPs@SiO $\mathrm{SH}_{2} @ \mathrm{NF} / \mathrm{PEG} / \mathrm{TCPP}$ with or without $808 \mathrm{~nm}$ laser irradiation. The overall cytotoxicity results from the Live/Dead ${ }^{\mathrm{TM}}$ assay were similar to those of the MTT assay. CLSM images showed the degree of cell death (green emission: live cell, calcein-AM/red emission: dead cell, ethidium homodimer-1). When only PBS was applied, a strong green emission was seen in all samples in normoxic and hypoxic conditions regardless of laser irradiation (Figure 7). In free TCPP, however, almost all cells were killed under a $660 \mathrm{~nm}$ laser or normoxic conditions, whereas most cells were live under a no-laser or hypoxic conditions, showing a low intensity of red fluorescence. As with the MTT assay, UCNPs@SiO $-\mathrm{NH}_{2} @ \mathrm{FA} / \mathrm{PEG}$ had a weak cell killing effect in all cases of laser or oxygen presence. In contrast, UCNPs@SiO $\mathrm{SH}_{2}-\mathrm{NH}_{2} @ \mathrm{FA} / \mathrm{PEG} / \mathrm{TCPP}$ showed a strong red emission upon $808 \mathrm{~nm}$ laser irradiation, and all HeLa cells appeared to be dead in normoxia. Laser irradiation did not show a significant effect of cancer cell death due to a low production of singlet oxygen in hypoxic conditions. Nonetheless, a significant fraction of cells was dead even in hypoxia for UCNPs@SiO ${ }_{2}-\mathrm{NH}_{2} @ \mathrm{FA} / \mathrm{PEG} / \mathrm{TCPP}$ plus the $808 \mathrm{~nm}$ laser. As shown in Figure 8A, $\mathrm{B}$, UCNPs@SiO $2-\mathrm{NH}_{2} @ \mathrm{FA} / \mathrm{PEG} / \mathrm{TCPP}$ displayed a clear cytotoxicity to cells of $\sim 300 \mu \mathrm{m}$-spheroids in normoxia with the $808 \mathrm{~nm}$ laser, as proven by the widespread red fluorescence color, and penetrated deep into the spheroids (10-80 $\mu \mathrm{m}$ Z-track images from slices with a 10- $\mu \mathrm{m}$ step size). However, a negligible 
cytotoxicity was shown in the spheroids treated with UCNPs@SiO $\mathrm{NH}_{2} @ \mathrm{FA} / \mathrm{PEG} / \mathrm{TCPP}$ in hypoxia with the $808 \mathrm{~nm}$ laser and in normoxia without the $808 \mathrm{~nm}$ laser (Figure 8B). This finding indicated that UCNPs@SiO $2-\mathrm{NH}_{2} @ \mathrm{FA} / \mathrm{PEG} / \mathrm{TCPP}$ would presumably have the practical potential to have a photodynamic antitumor efficacy for the relevant tumor in vivo.

\subsection{Cellular Uptake of UCNPs@SiO $2-\mathrm{NH}_{2} @ F A / P E G / T C P P$ into HeLa Cells}

The cellular uptake of UCNP conjugates into HeLa cancer cells was visualized by Bio-TEM and CLSM. As shown in Figure 9A, UCNPs@SiO $2-\mathrm{NH}_{2} @ \mathrm{FA} / \mathrm{PEG} / \mathrm{TCPP}$ was internalized into the cells in $10 \mathrm{~min}$ (red fluorescence for conjugated TCPP). This result indicates that the UCNPs are taken up by the cells, presumably due to folic acid-mediated endocytosis and small size-based nonspecific uptake [55]. To confirm the internalization of UCNPs@SiO $-\mathrm{NH}_{2} @ F A / P E G / T C P P$ in HeLa cells, cells were photographed by Bio-TEM (Figure 9B). The diameter of HeLa cells was estimated to be 20-40 $\mu \mathrm{m}$, and UCNPs@SiO $2-\mathrm{NH}_{2} @ \mathrm{FA} / \mathrm{PEG} / \mathrm{TCPP}$ was scattered inside or near cells, similar to the original shape of UCNPs@SiO $\mathrm{SH}_{2} @ \mathrm{FA} / \mathrm{PEG} / \mathrm{TCPP}$. In addition, the uptake of UCNPs@SiO $2-\mathrm{NH}_{2} @ \mathrm{FA} / \mathrm{PEG} / \mathrm{TCPP}$ was observed in an in vitro spheroid model system mimicking tumor tissues in vivo (Figure 9C). The Z-stack images of spheroids were obtained from slices with a $20-\mu \mathrm{m}$ step size and showed red fluorescence. Based on the spheroid result, UCNPs@SiO $-\mathrm{NH}_{2} @ \mathrm{FA} / \mathrm{PEG} / \mathrm{TCPP}$ was predicted to penetrate into tumors in vivo. Despite the absence of in vivo tumor ablation, we believe that these overall in vitro data demonstrate the great potential for tumor targeting and penetration of our UCNPs platform.
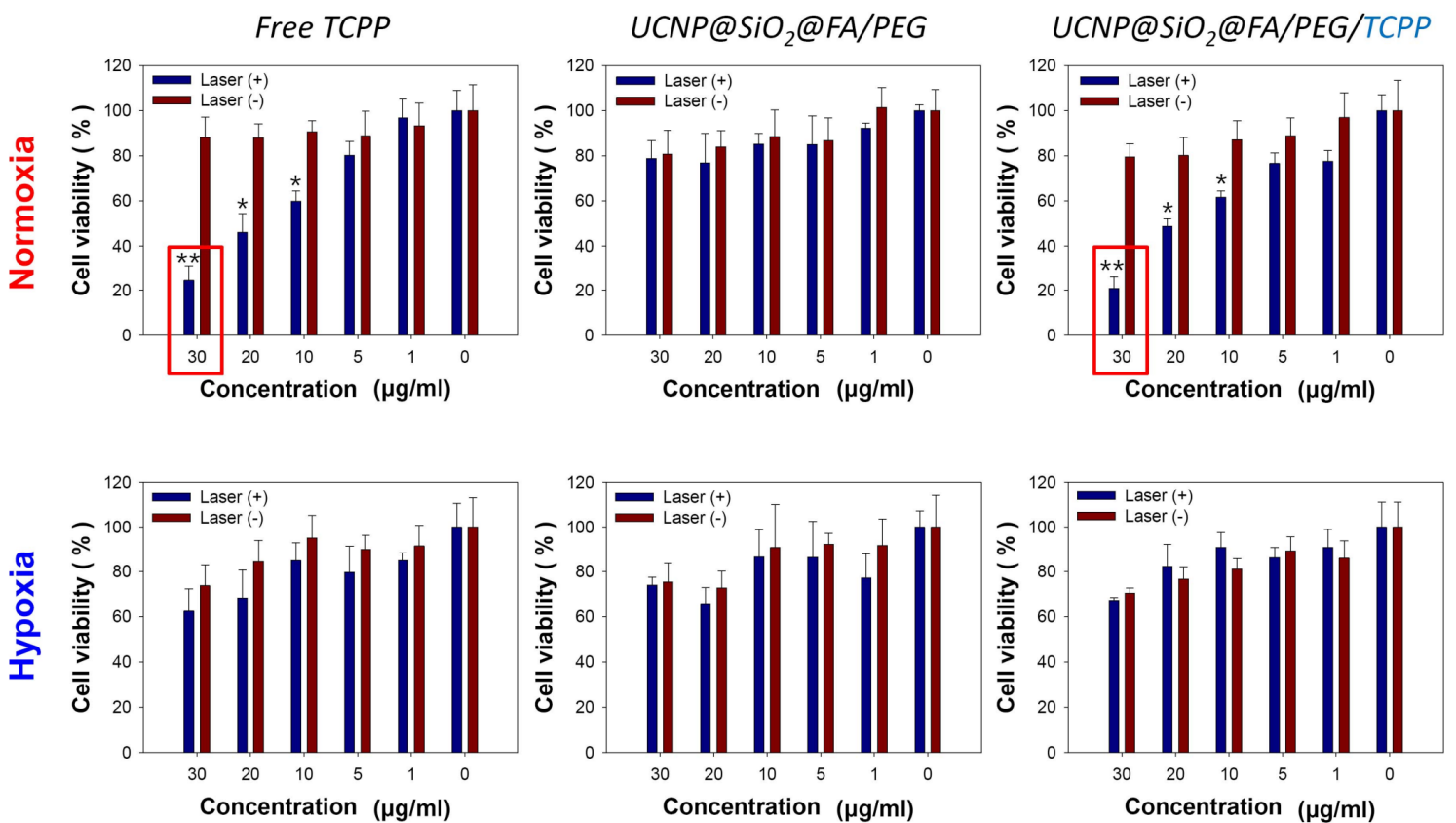

Figure 6. Cytotoxicity evaluation of free TCPP, UCNP@ $\mathrm{SiO}_{2} @$ FA/PEG, and UCNP@ $\mathrm{SiO}_{2} @ \mathrm{FA} / \mathrm{PEG} / \mathrm{TCPP}$ under normoxic or hypoxic conditions with or without laser irradiation $(660 \mathrm{~nm}$, $30 \mathrm{~min}, 10 \mathrm{~mW} / \mathrm{cm}^{2}$ for free TCPP; $808 \mathrm{~nm}, 30 \mathrm{~min}, 1.5 \mathrm{~W} / \mathrm{cm}^{2}$ for others). Data are presented as means $\pm \operatorname{SDs}(n=7) .{ }^{*} p<0.003$ over Laser(-) and ${ }^{* *} p<0.001$ over Laser(-). 

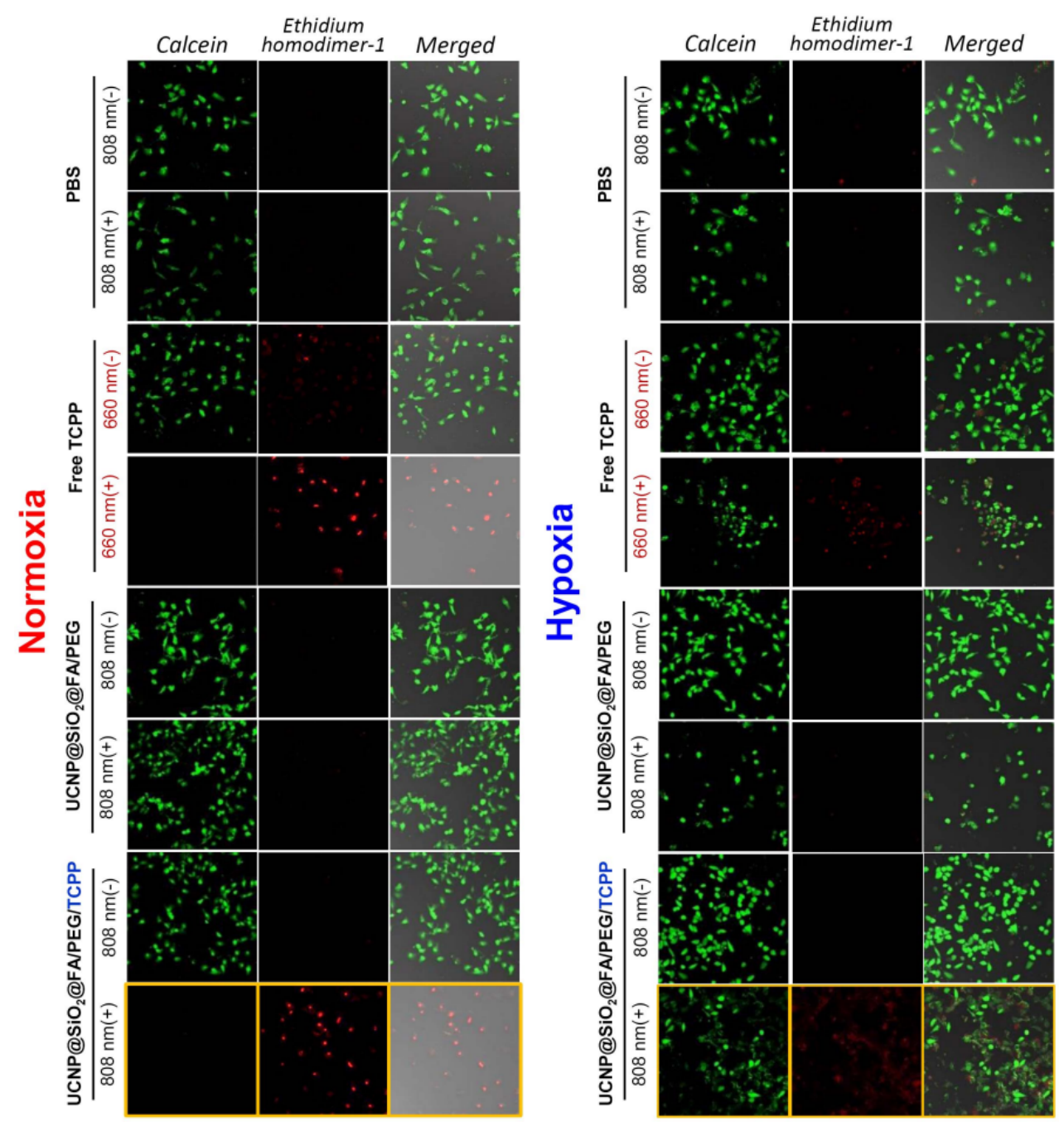

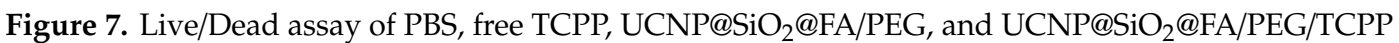
under normoxic or hypoxic conditions with or without laser irradiation $\left(660 \mathrm{~nm}, 30 \mathrm{~min}, 10 \mathrm{~mW} / \mathrm{cm}^{2}\right.$ for free TCPP; $808 \mathrm{~nm}, 30 \mathrm{~min}, 1.5 \mathrm{~W} / \mathrm{cm}^{2}$ for others).
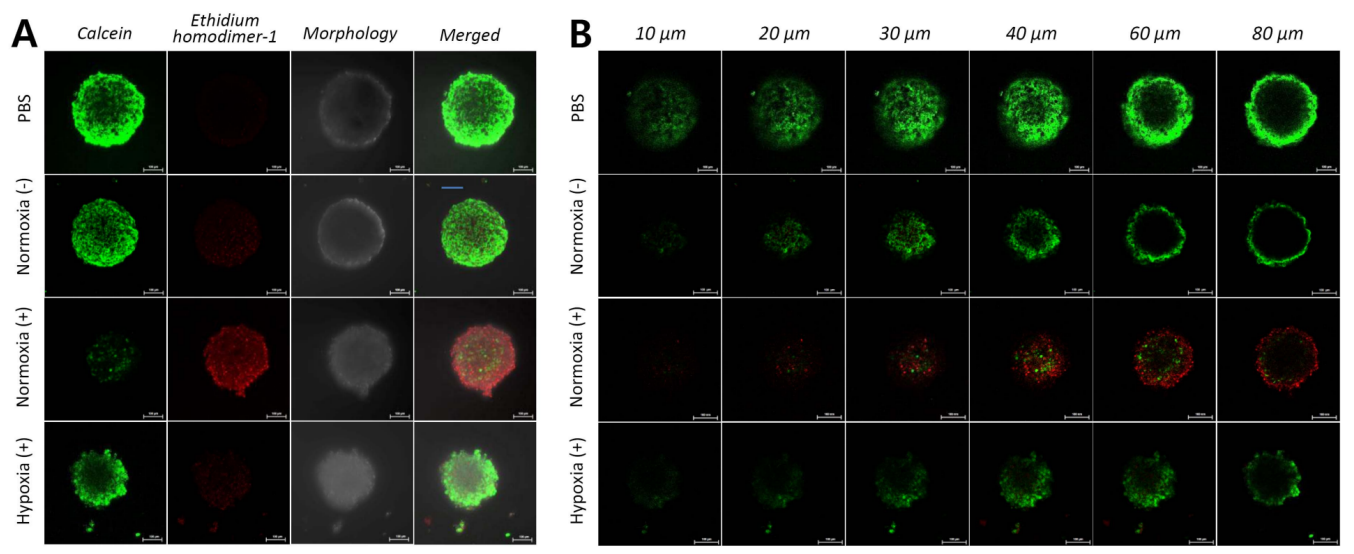

Figure 8. (A) Images for the Live/Dead assay in 3D multicellular HeLa cell spheroids under the predetermined conditions $\left(808 \mathrm{~nm}, 30 \mathrm{~min}, 1.5 \mathrm{~W} / \mathrm{cm}^{2}\right)$. (B) Z-stack images of six 10-20- $\mu \mathrm{m}$ slices in the HeLa cell spheroids. 


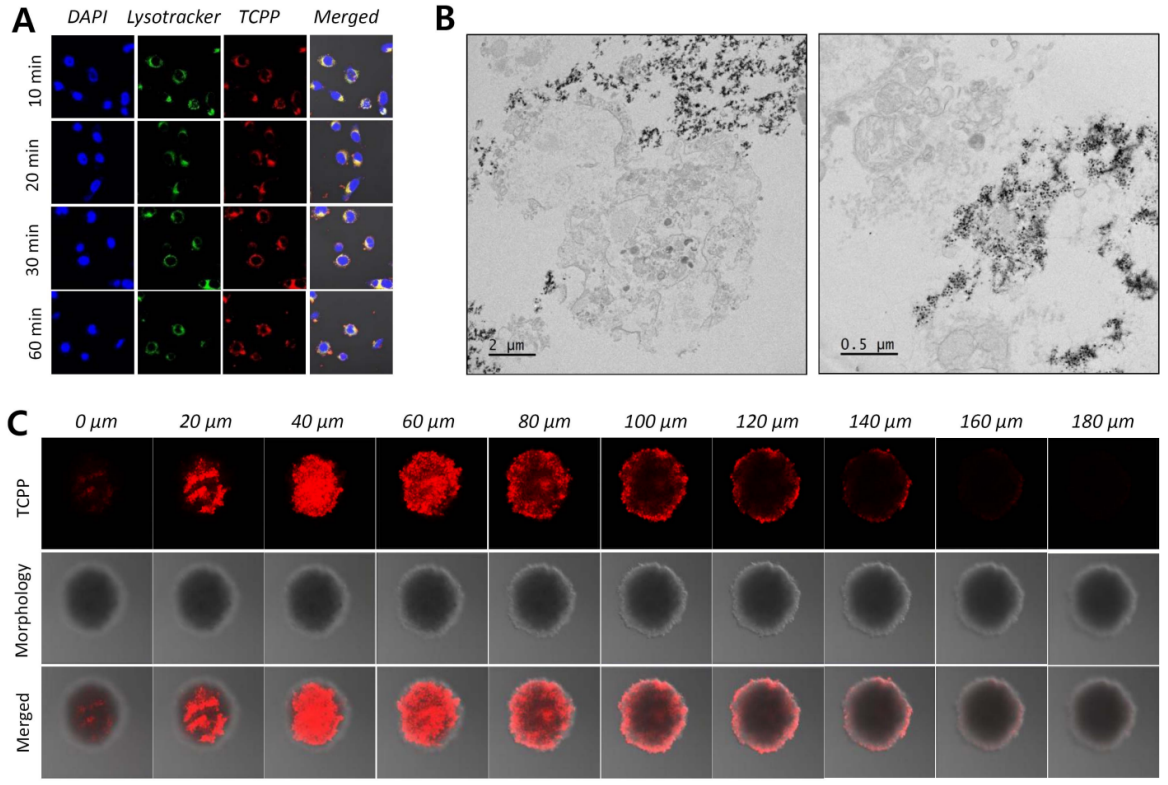

Figure 9. (A) Two-dimensional monolayer images of HeLa cells treated with core-shell upconverting nanoparticles surface-modified with silica, PEG-folic acid (FA/PEG), and TCPP

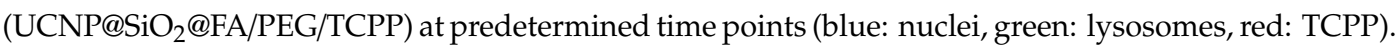
(B) Bio-TEM images of HeLa cells treated with UCNP@SiO $@$ @FA/PEG/TCPP. (C) In vitro spheroid model images (Z-stack of ten $20-\mu \mathrm{m}$ slices) for predicting the cellular uptake of UCNP conjugates into three-dimensional tumor tissues.

\section{Conclusions}

In summary, highly singlet oxygen-generating upconverting nanoparticles respectively doped with erbium and lutetium for the core and shell (UCNPs@SiO $\left.\mathrm{S}_{2}-\mathrm{NH}_{2} @ \mathrm{FA} / \mathrm{PEG} / \mathrm{TCPP}\right)$ were fabricated. These nanoparticles were $\sim 50 \mathrm{~nm}$ in size and strongly emitted red fluorescence with little green fluorescence, which was considered optimal for the activation of a $660 \mathrm{~nm}$-responsive-photodynamic TCPP agent. The UCNPs generated singlet oxygen and thus killed HeLa cells under $808 \mathrm{~nm}$ laser irradiation and normoxic conditions. Furthermore, the UCNPs were well-internalized into the HeLa cell monolayer and three-dimensional cell spheroids, presumably due to the folic acid ligand and small particle size. These overall results suggest that UCNPs could be a potential therapeutic platform for ablating tumors.

Author Contributions: Conceptualization: Y.S.Y., K.L. and X.T.L.; Methodology, K.L., H.K.K. and N.T.N.; Software: H.K.K.; Validation: X.T.L. and H.K.K.; Formal analysis: K.L. and X.T.L.; Investigation: E.S.L., K.T.O.; Resources: H.-G.C.; Data curation: H.K.K., X.T.L. and E.S.L., Y.S.Y.; Writing-original draft preparation: K.L. and Y.S.Y.; Writing-review and editing: E.S.L., K.T.O., Y.S.Y. and H.-G.C.; Visualization: Y.S.Y.; Supervision: Y.S.Y.; Project administration: Y.S.Y.; Funding acquisition: Y.S.Y. All authors have read and agreed to the published version of the manuscript.

Funding: This work was supported by National Research Foundation of Korea (NRF) grants funded by the Korean government (MSIT) (No. NRF-2019R1A2C2085292 and No. NRF-2019R1A5A2027340).

Conflicts of Interest: The authors declare no conflict of interest.

\section{References}

1. Castano, A.P.; Mroz, P.; Hamblin, M.R. Photodynamic therapy and anti-tumour immunity. Nat. Rev. Cancer 2006, 6, 535-545. [CrossRef] [PubMed]

2. Phuong, P.T.T.; Lee, S.; Lee, C.; Seo, B.; Park, S.; Oh, K.T.; Lee, E.S.; Choi, H.-G.; Shin, B.S.; Youn, Y.S. Beta-carotene-bound albumin nanoparticles modified with chlorin e6 for breast tumor ablation based on photodynamic therapy. Colloids Surf. B Biointerfaces 2018, 171, 123-133. [CrossRef] [PubMed] 
3. Kim, J.; Jo, Y.-U.; Na, K. Photodynamic therapy with smart nanomedicine. Arch. Pharm. Res. 2020, 43, $22-31$. [CrossRef] [PubMed]

4. Dolmans, D.E.; Fukumura, D.; Jain, R.K. Photodynamic therapy for cancer. Nat. Rev. Cancer 2003, 3, $380-387$. [CrossRef] [PubMed]

5. Lucky, S.S.; Soo, K.C.; Zhang, Y. Nanoparticles in photodynamic therapy. Chem. Rev. 2015, 115, 1990-2042. [CrossRef]

6. Jeon, G.; Ko, Y.T. Enhanced photodyamic therapy via photosensitizer-loaded nanoparticles for cancer treatment. J. Pharm. Investig. 2019, 49, 1-8. [CrossRef]

7. Buytaert, E.; Dewaele, M.; Agostinis, P. Molecular effectors of multiple cell death pathways initiated by photodynamic therapy. Biochim. Biophys. Acta Rev. Cancer 2007, 1776, 86-107. [CrossRef]

8. Calixto, G.M.F.; Bernegossi, J.; De Freitas, L.M.; Fontana, C.R.; Chorilli, M. Nanotechnology-based drug delivery systems for photodynamic therapy of cancer: A Review. Molecules 2016, 21, 342. [CrossRef]

9. Hwang, H.S.; Shin, H.; Han, J.; Na, K. Combination of photodynamic therapy (PDT) and anti-tumor immunity in cancer therapy. J. Pharm. Investig. 2018, 48, 143-151. [CrossRef]

10. Avci, P.; Gupta, A.; Sadasivam, M.; Vecchio, D.; Pam, Z.; Pam, N.; Hamblin, M.R. Low-level laser (light) therapy (LLLT) in skin: Stimulating, healing, restoring. Semin. Cutan. Med. Surg. 2013, 32, 41-52.

11. Kang, J.K.; Kim, J.C.; Shin, Y.; Han, S.M.; Won, W.R.; Her, J.; Park, J.Y.; Oh, K.T. Principles and applications of nanomaterial-based hyperthermia in cancer therapy. Arch. Pharm. Res. 2020, 43, 46-57. [CrossRef] [PubMed]

12. Lee, C.; Hwang, H.S.; Lee, S.; Kim, B.; Kim, J.O.; Oh, K.T.; Lee, E.S.; Choi, H.G.; Youn, Y.S. Rabies virus-inspired silica-coated gold nanorods as a photothermal therapeutic platform for treating brain tumors. Adv. Mater. 2017, 29, 1605563. [CrossRef] [PubMed]

13. Wu, S.; Butt, H.J. Near-infrared-sensitive materials based on upconverting nanoparticles. Adv. Mater. 2016, 28, 1208-1226. [CrossRef] [PubMed]

14. Le, X.T.; Youn, Y.S. Emerging NIR light-responsive delivery systems based on lanthanide-doped upconverting nanoparticles. Arch. Pharm. Res. 2020, 43, 134-152. [CrossRef]

15. Bagheri, A.; Arandiyan, H.; Boyer, C.; Lim, M. Lanthanide-doped upconversion nanoparticles: Emerging intelligent light-activated drug delivery systems. Adv. Sci. 2016, 3, 1500437. [CrossRef]

16. Demina, P.A.; Khaydukov, E.V.; Sholina, N.V.; Rocheva, V.V.; Khochenkov, D.A.; Akasov, R.A.; Generalova, A.N. Upconversion nanoparticles with anti-Stokes luminescence as bioimaging agents. EPJ Web Conf. 2018, 190, 04005. [CrossRef]

17. Liu, B.; Chen, Y.; Li, C.; He, F.; Hou, Z.; Huang, S.; Zhu, H.; Chen, X.; Lin, J. Poly(Acrylic Acid) modification of $\mathrm{Nd}^{3+}$-sensitized upconversion nanophosphors for highly efficient UCL imaging and $\mathrm{pH}$-responsive drug delivery. Adv. Funct. Mater. 2015, 25, 4717-4729. [CrossRef]

18. Im, S.J.; Lee, S.Y.; Park, Y.I. Recent trends in photodynamic therapy using upconversion nanoparticles. Appl. Chem. Eng. 2018, 29, 138-146.

19. Lai, W.-F.; Rogach, A.L.; Wong, W.-T. Molecular design of upconversion nanoparticles for gene delivery. Chem. Sci. 2017, 8, 7339-7358. [CrossRef]

20. Wen, S.; Zhou, J.; Zheng, K.; Bednarkiewicz, A.; Liu, X.; Jin, D. Advances in highly doped upconversion nanoparticles. Nat. Commun. 2018, 9, 2415. [CrossRef]

21. Wang, J.; Deng, R.; MacDonald, M.A.; Chen, B.; Yuan, J.; Wang, F.; Chi, D.; Hor, T.S.A.; Zhang, P.; Liu, G.; et al. Enhancing multiphoton upconversion through energy clustering at sublattice level. Nat. Mater. 2014, 13, 157-162. [CrossRef] [PubMed]

22. Chen, C.; Li, C.; Shi, Z. Current advances in lanthanide-doped upconversion nanostructures for detection and bioapplication. Adv. Sci. 2016, 3, 1600029. [CrossRef] [PubMed]

23. Zhan, Q.; Wang, B.; Wen, X.; He, S. Controlling the excitation of upconverting luminescence for biomedical theranostics: Neodymium sensitizing. Opt. Mater. Express 2016, 6, 1011-1023. [CrossRef]

24. Wen, H.; Zhu, H.; Chen, X.; Hung, T.F.; Wang, B.; Zhu, G.; Yu, S.F.; Wang, F. Upconverting near-infrared light through energy management in core-shell-shell nanoparticles. Angew. Chem. Int. Ed. Engl. 2013, 52, 13419-13423. [CrossRef] [PubMed]

25. Zhong, Y.; Tian, G.; Gu, Z.; Yang, Y.; Gu, L.; Zhao, Y.; Ma, Y.; Yao, J. Elimination of photon quenching by a transition layer to fabricate a quenching-shield sandwich structure for $800 \mathrm{~nm}$ excited upconversion luminescence of $\mathrm{Nd}^{3+}$-sensitized nanoparticles. Adv. Mater. 2014, 26, 2831-2837. [CrossRef] 
26. Hu, J.; Zhan, S.; Wu, X.; Hu, S.; Wu, S.; Liu, Y. Core/shell upconversion nanoparticles with intense fluorescence for detecting doxorubicin in vivo. RSC Adv. 2018, 8, 21505-21512. [CrossRef]

27. Nguyen, H.T.; Tran, T.T.P.; Jin, S.G.; Yong, C.S.; Truong, D.H.; Tran, T.H.; Kim, J.O. Combined hyperthermia and chemotherapy as a synergistic anticancer treatment. J. Pharm. Investig. 2019, 49, 519-526.

28. Chen, Q.; Wang, C.; Cheng, L.; He, W.; Cheng, Z.; Liu, Z. Protein modified upconversion nanoparticles for imaging-guided combined photothermal and photodynamic therapy. Biomaterials 2014, 35, 2915-2923. [CrossRef]

29. Wang, C.; Tao, H.; Cheng, L.; Liu, Z. Near-infrared light induced in vivo photodynamic therapy of cancer based on upconversion nanoparticles. Biomaterials 2011, 32, 6145-6154. [CrossRef]

30. Wang, C.; Cheng, L.; Liu, Z. Upconversion nanoparticles for photodynamic therapy and other cancer therapeutics. Theranostics 2013,3,317-330. [CrossRef]

31. Sim, T.; Lim, C.; Hoang, N.H.; Shin, Y.; Kim, J.C.; Park, J.Y.; Her, J.; Lee, E.S.; Youn, Y.S.; Oh, K.T. An on-demand $\mathrm{pH}$-sensitive nanocluster for cancer treatment by combining photothermal therapy and chemotherapy. Pharmaceutics 2020, 12, 839. [CrossRef] [PubMed]

32. Han, S.; Hwang, B.W.; Jeon, E.Y.; Jung, D.; Lee, G.H.; Keum, D.H.; Kim, K.S.; Yun, S.H.; Cha, H.J.; Hahn, S.K. Upconversion nanoparticles/hyaluronate-rose bengal conjugate complex for noninvasive photochemical tissue bonding. ACS Nano 2017, 11, 9979-9988. [CrossRef] [PubMed]

33. Gnanasammandhan, M.K.; Idris, N.M.; Bansal, A.; Huang, K.; Zhang, Y. Near-IR photoactivation using mesoporous silica-coated $\mathrm{NaYF}_{4}$ : Yb,Er/Tm upconversion nanoparticles. Nat. Protoc. 2016, 11, 688-713. [CrossRef] [PubMed]

34. Wang, F.; Deng, R.; Liu, X. Preparation of core-shell $\mathrm{NaGdF}_{4}$ nanoparticles doped with luminescent lanthanide ions to be used as upconversion-based probes. Nat. Protoc. 2014, 9, 1634-1644. [CrossRef]

35. Xie, X.; Gao, N.; Deng, R.; Sun, Q.; Xu, Q.-H.; Liu, X. Mechanistic investigation of photon upconversion in $\mathrm{nd}^{3+}$-sensitized core-shell nanoparticles. J. Am. Chem. Soc. 2013, 135, 12608-12611. [CrossRef]

36. Dongdong, L.; Qiyue, S.; Yan, D.; Jiang, J. Phase-, shape- and size-controlled synthesis of $\mathrm{NaYF}_{4}: \mathrm{Yb}^{3+}, \mathrm{Er}^{3+}$ nanoparticles using rare-earth acetate precursors. J. Rare Earths 2014, 32, 1032-1036.

37. He, S.; Johnson, N.J.; Nguyen Huu, V.A.; Huang, Y.; Almutairi, A. Leveraging spectral matching between photosensitizers and upconversion nanoparticles for $808 \mathrm{~nm}$-activated photodynamic therapy. Chem. Mater. 2018, 30, 3991-4000. [CrossRef]

38. Lin, S.-L.; Chen, Z.-R.; Chang, C.A. $\mathrm{Nd}^{3+}$ sensitized core-shell-shell nanocomposites loaded with IR806 dye for photothermal therapy and up-conversion luminescence imaging by a single wavelength NIR light irradiation. Nanotheranostics 2018, 2, 243-257. [CrossRef]

39. Alonso-Cristobal, P.; Vilela, P.; El-Sagheer, A.; Lopez-Cabarcos, E.; Brown, T.; Muskens, O.; Rubio-Retama, J.; Kanaras, A. Highly sensitive DNA sensor based on upconversion nanoparticles and graphene oxide. ACS Appl. Mater. Interfaces 2015, 7, 12422-12429. [CrossRef]

40. Wang, D.; Xue, B.; Kong, X.; Tu, L.; Liu, X.; Zhang, Y.; Chang, Y.; Luo, Y.; Zhao, H.; Zhang, H. 808 nm driven $\mathrm{Nd}^{3+}$-sensitized upconversion nanostructures for photodynamic therapy and simultaneous fluorescence imaging. Nanoscale 2015, 7, 190-197. [CrossRef]

41. Ai, F.; Ju, Q.; Zhang, X.; Chen, X.; Wang, F.; Zhu, G. A core-shell-shell nanoplatform upconverting near-infrared light at $808 \mathrm{~nm}$ for luminescence imaging and photodynamic therapy of cancer. Sci. Rep. 2015, 5, 10785. [CrossRef] [PubMed]

42. Wei, G.; Yan, M.; Ma, L.; Wang, C. Photothermal and photodynamic therapy reagents based on rGO- $\mathrm{C}_{6} \mathrm{H}_{4}-\mathrm{COOH}$. RSC Adv. 2016, 6, 3748-3755. [CrossRef]

43. Zhang, S.; Lv, H.; Zhao, J.; Cheng, M.; Sun, S. Synthesis of porphyrin-conjugated silica-coated Au nanorods for synergistic photothermal therapy and photodynamic therapy of tumor. Nanotechnology 2019, 30, 265102. [CrossRef] [PubMed]

44. Sun, M.; Xu, L.; Ma, W.; Wu, X.; Kuang, H.; Wang, L.; Xu, C. Hierarchical plasmonic nanorods and upconversion core-satellite nanoassemblies for multimodal imaging-guided combination phototherapy. Adv. Mater. 2016, 28, 898-904. [CrossRef] [PubMed]

45. Yi, Z.; Zeng, S.; Lu, W.; Wang, H.; Rao, L.; Liu, H.; Hao, J. Synergistic dual-modality in vivo upconversion luminescence/X-ray imaging and tracking of amine-functionalized NaYbF4: Er nanoprobes. ACS Appl. Mater Interfaces 2014, 6, 3839-3846. [CrossRef] [PubMed] 
46. Park, S.; Kim, H.; Lim, S.C.; Lim, K.; Lee, E.S.; Oh, K.T.; Choi, H.-G.; Youn, Y.S. Gold nanocluster-loaded hybrid albumin nanoparticles with fluorescence-based optical visualization and photothermal conversion for tumor detection/ablation. J. Control. Release 2019, 304, 7-18. [CrossRef]

47. Byeon, H.J.; Lee, S.; Min, S.Y.; Lee, E.S.; Shin, B.S.; Choi, H.-G.; Youn, Y.S. Doxorubicin-loaded nanoparticles consisted of cationic-And mannose-modified-albumins for dual-targeting in brain tumors. J. Control. Release 2016, 225, 301-313. [CrossRef]

48. Lee, C.; Lim, K.; Kim, S.S.; Lee, E.S.; Oh, K.T.; Choi, H.-G.; Youn, Y.S. Chlorella-gold nanorods hydrogels generating photosynthesis-derived oxygen and mild heat for the treatment of hypoxic breast cancer. J. Control. Release 2019, 294, 77-90. [CrossRef]

49. Xu, X.; Cui, Y.; Bu, H.; Chen, J.; Li, Y.; Tang, G.; Wang, L.-Q. A photosensitizer loaded hemoglobin-polymer conjugate as a nanocarrier for enhanced photodynamic therapy. J. Mater. Chem. B 2018, 6, 1825-1833. [CrossRef]

50. Lahtinen, S.; Lyytikainen, A.; Pakkila, H.; Homppi, E.; Perala, N.; Lastusaari, M.; Soukka, T. Disintegration of hexagonal $\mathrm{NaYF}_{4}: \mathrm{Yb}^{3+}, \mathrm{Er}^{3+}$ upconverting nanoparticles in aqueous media: The role of fluoride in solubility equilibrium. J. Phys. Chem. C 2016, 121, 656-665. [CrossRef]

51. Himmelstoß, S.F.; Hirsch, T. Long-term colloidal and chemical stability in aqueous media of $\mathrm{NaYF}_{4}$-type upconversion nanoparticles modified by ligand-exchange. Part. Part. Syst. Charact. 2019, 36, 1900235. [CrossRef]

52. Muhr, V.; Wilhelm, S.; Hirsch, T.; Wolfbeis, O.S. Upconversion nanoparticles: From hydrophobic to hydrophilic surfaces. Acc. Chem. Res. 2014, 47, 3481-3493. [CrossRef] [PubMed]

53. Li, N.; Wen, X.; Liu, J.; Wang, B.; Zhan, Q.; He, S. Yb ${ }^{3+}$-enhanced UCNP@SiO ${ }_{2}$ nanocomposites for consecutive imaging, photothermal-controlled drug delivery and cancer therapy. Opt. Mater. Express 2016, 6, 1161-1171. [CrossRef]

54. Liu, J.-N.; Bu, W.-B.; Shi, J.-L. Silica coated upconversion nanoparticles: A versatile platform for the development of efficient theranostics. Acc. Chem. Res. 2015, 48, 1797-1805. [CrossRef]

55. Sim, T.; Lim, C.; Hoang, N.H.; Oh, K.T. Recent advance of pH-sensitive nanocarriers targeting solid tumors. J. Pharm. Investig. 2017, 47, 383-394. [CrossRef]

56. Cho, H.-J. Recent progresses in the development of hyaluronic acid-based nanosystems for tumor-targeted drug delivery and cancer imaging. J. Pharm. Investig. 2020, 50, 115-129. [CrossRef]

57. Wang, D.; Liu, B.; Quan, Z.; Li, C.; Hou, Z.; Xing, B.; Lin, J. New advances on the marrying of UCNPs and photothermal agents for imaging-guided diagnosis and the therapy of tumors. J. Mater. Chem. B 2017, 5, 2209-2230. [CrossRef]

58. Lv, R.; Yang, P.; Chen, G.; Gai, S.; Xu, J.; Prasad, P.N. Dopamine-mediated photothermal theranostics combined with up-conversion platform under near infrared light. Sci. Rep. 2017, 7, 13562. [CrossRef]

59. Nadort, A.; Sreenivasan, V.K.; Song, Z.; Grebenik, E.A.; Nechaev, A.V.; Semchishen, V.A.; Panchenko, V.Y.; Zvyagin, A.V. Quantitative imaging of single upconversion nanoparticles in biological tissue. PLoS ONE 2013, 8, e63292. [CrossRef]

60. Li, P.; Yan, Y.; Chen, B.; Zhang, P.; Wang, S.; Zhou, J.; Fan, H.; Wang, Y.; Huang, X. Lanthanide-doped upconversion nanoparticles complexed with nano-oxide graphene used for upconversion fluorescence imaging and photothermal therapy. Biomater. Sci. 2018, 6, 877-884. [CrossRef]

61. Cheng, L.; Jiang, D.; Kamkaew, A.; Valdovinos, H.F.; Im, H.J.; Feng, L.; England, C.G.; Goel, S.; Barnhart, T.E.; Liu, Z.; et al. Renal-clearable PEGylated porphyrin nanoparticles for image-guided photodynamic cancer therapy. Adv. Funct. Mater. 2017, 27, 1702928. [CrossRef] [PubMed]

62. Zhao, X.; Zhang, J.; Shi, L.; Xian, M.; Dong, C.; Shuang, S. Folic acid-conjugated carbon dots as green fluorescent probes based on cellular targeting imaging for recognizing cancer cells. RSC Adv. 2017, 7, 42159-42167. [CrossRef]

63. Müller, C.; Schubiger, P.A.; Schibli, R. In vitro and in vivo targeting of different folate receptor-positive cancer cell lines with a novel ${ }^{99 \mathrm{~m}}$ Tc-radiofolate tracer. Eur. J. Nucl. Med. Mol. Imaging 2006, 33, 1162-1170. [CrossRef] [PubMed]

64. Russell-Jones, G.; McTavish, K.; McEwan, J.; Rice, J.; Nowotnik, D. Vitamin-mediated targeting as a potential mechanism to increase drug uptake by tumours. J. Inorg. Biochem. 2004, 98, 1625-1633. [CrossRef] [PubMed] 
65. Fang, L.; Hu, Q.; Jiang, K.; Zhang, X.; Li, B.; Cui, Y.; Yang, Y.; Qian, G. An inner light integrated metal-organic framework photodynamic therapy system for effective elimination of deep-seated tumor cells. J. Solid State Chem. 2019, 276, 205-209. [CrossRef]

66. Baskaran, R.; Lee, J.; Yang, S.-G. Clinical development of photodynamic agents and therapeutic applications. Biomater. Res. 2018, 22, 303-310. [CrossRef] [PubMed]

67. Hu, Z.; Pan, Y.; Wang, J.; Chen, J.; Li, J.; Ren, L. Meso-tetra (carboxyphenyl) porphyrin (TCPP) nanoparticles were internalized by SW480 cells by a clathrin-mediated endocytosis pathway to induce high photocytotoxicity. Biomed. Pharm. 2009, 63, 155-164. [CrossRef]

68. Hayashi, K.; Nakamura, M.; Miki, H.; Ozaki, S.; Abe, M.; Matsumoto, T.; Ishimura, K. Near-infrared fluorescent silica/porphyrin hybrid nanorings for in vivo cancer imaging. Adv. Funct. Mater. 2012, 22, 3539-3546. [CrossRef]

Publisher's Note: MDPI stays neutral with regard to jurisdictional claims in published maps and institutional affiliations.

(C) 2020 by the authors. Licensee MDPI, Basel, Switzerland. This article is an open access article distributed under the terms and conditions of the Creative Commons Attribution (CC BY) license (http://creativecommons.org/licenses/by/4.0/). 